\title{
Leadership Succession Impact on School Culture: A Case Study at a Faith Based Secondary School in Indonesia
}

\author{
Ignatius Darma Juwono and Tessar Harfin Harly
}

\begin{abstract}
School principals hold responsibilities which affected how the school functions. Values and beliefs held by a principal will influence how he/she articulate school's mission and vision. In the context of Indonesian education system, there can be change in leadership position at a school (either by promotion, rotation, or retirement), causing succession to occur and changes in the practice of a school. The changes in practice in school can lead to changes of the school culture. This research aims to seek how a leadership succession in a school organization affect the school culture in a faith-based private school in Jakarta. This is a qualitative research conducted by interviewing two principal (one former principal and currently employed as principal) within a school regarding how these individuals lead the organization at the time they are employed as school principal. Four teachers were also participate in the research to provide description of differences in the way the principals lead the school. Finding of the research suggests that there are changes in aspects of the school culture especially in the meaning of traditional activities and rites, as well as the nature of relationship among teachers in the organization. These changes were related to what values and belief the principals hold firm and some context of the school organization. The implication of the finding suggest that for every leadership succession, one organization should expect changes to happen. Preparing and orienting new leader to the values of the school should precede the succession process in order to maintain the school culture.
\end{abstract}

Index Terms-Leadership succession, school culture, school leadership.

\section{INTRODUCTION}

A principal is the highest authority in school organization context who serves as a leader for its organization. As a leader, principal directs the organization toward desired goals of the organization [1]. Principal needs to coordinate the work within the organization so that the instructional process run smoothly; students can attain highest achievement possible; motivate the teachers and administrative staff as well as creating culture of learning and a positive environment.

Despite the huge responsibility, a principal will not serve a school forever. There will be changes in the personnel caused by retirement, resignation of the previous principal, or promotion to district or national level. In Indonesia's education system, a principal will only serve in one school for maximum two periods of four years span [2]. After such the second term, the principal will be relocated to different school

Manuscript received August, 31, 2015; revised January 7, 2016.

Ignatius Darma Juwono and Tessar Harfin Harly are with Atma Jaya Catholic University of Indonesia, School of Pscyhology, Indonesia (e-mail: darma.juwono@atmajaya.ac.id). or another district level. Changes in the principal can also be caused of accident, sudden death of the principal, or retirement of the principal. The change in the principal creates a situation known as leadership succession.

Leadership succession is change process in the personnel acting as a leader. In the school setting, this means that change of principal [3]. Succession process can create instability in the organization, including school. The instability might be due to changing supervisor and subordinate communication, different decision making strategies, different priorities stated by new leader, and many different practices in the organization. All these changes might cause changes in daily practices at the school, which might lead up to change in the school culture.

Defined as a collection of written and unwritten rules within an organization, school culture underlies assumptions held by the principal which serve as a differing quality with different school organization [4]. School culture should be reflected in the values, tradition, assumption, and norms unique in an organization [5]. School culture is not merely written regulation, daily practices by the personnel will also be indication of a school culture [6].

School culture will have an impact on how members of the school community think or act [6]. It also focuses the priority of the organization. For example, a school with strong sport achievement culture will prioritize building sporting facilities than improving language laboratory. School culture can also influence sense of community within the organization, which should also be related to motivation of the school (both teachers, staff, and students) to put forth their best effort.

This research intends to describe the leadership succession in a faith based secondary school in Indonesia. The organization experienced change in the principal after 4 years leading the organization. This article will describe how change in principal influences changing in components of school culture.

\section{A. School Culture}

School culture is a collection of both written and unwritten regulation which signifies the underlying beliefs, attitude, and values unique to one organization [4]. It shows values, tradition, assumption, and set of actions accepted within a school organization [5].

Although it refers to underlying values, beliefs and assumptions in one organization, school culture could be identified through its stated vision and mission; norms within the school; values and beliefs shared within the community; tradition and rites unique to the school architectural design and artifacts; stories shared from generation to generation; as well as heroes or figures that is repeatedly looked as model for 
the school [6]-[8]. However, the school culture is not only aggregation of these factors, but overall integration of such factors.

School vision and mission are dreams to be achieved by the school [6]. These goals can orient the school and its members to plan and allocate their resources to attain them. Norms are different than written regulation that obliged teachers and students to act in certain way, but also influence the accepted way of behaving, communicating, and interacting among different members of the community. Norms can be tied to rules and regulations because it is the philosophical foundation that base every decisions made.

Rites and tradition within a school are integral part of school culture because these activities send messages to the community regarding what is held strongly in the organization [6]. A habit of principal greets every students and employees each morning can signifies that a welcoming and safe environment are top priority for the school. School culture can also be identified from the architectural design as well as the use of symbols and artifacts conveying deeper meaning. If a religious space is located in the center of a faith based school, it could mean that religious values and practice is highly regarded in the school. School's symbol and logo can also have deeper meaning that represent the school.

A hero is a person, whom the stories is repeatedly centered upon and passed on to different generation [6]. His/her action and words are repeatedly use as a model of behavior within the school. It could be the school's founder or a person whose spirits are reference to the organization (i.e. Saints that inspire a school). Sometime the school celebrates their patron in very specific way. These celebration and events to commemorate patron and figures also an indication of the school culture.

\section{B. School Leadership}

Leadership can be defined as process within a school organization to attain its desired goals [1], [9]. In this context leadership is an interactive process between leader, follower, and situation of the organization as shown in the Fig. 1 [10]. Therefore in analyzing leadership in school setting, one needs to bring context of the organization as well as the leadership behavior and follower's feedback of the behavior.

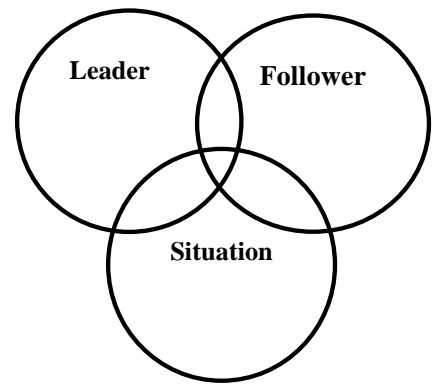

Fig. 1. Interactional framework for analyzing leadership.

Principal is the leader of school organization with immense responsibilities. He/she is the one directing the organization toward its desired goals. He needs to manage the yearly routine of academic year, collaborate with teachers to ensure the highest quality of instruction, developing and monitoring teachers' work, as well as ensuring the school values and regulation are followed [6], [11].

Within Indonesia's context, principal is the highest authority that lead the organization. However, some private schools in Indonesia is regulated by foundation board. This foundation board will manage the finance and organization in macro setting and leaving the principal to manage the target set by the foundation.

\section{Leadership Succession}

A principal will never stay on the same position forever. $\mathrm{He} / \mathrm{she}$ might move into different position for numerous reason (i.e. Promotion to district level, retirement, medical condition prohibiting he/she to function optimally or rotation to different school within district). This movement into different position will create a condition called leadership succession [12]. Succession can be defined as changes in leadership of an organization.

Fink and Brayman [13] stated that succession comprises of several stages, starting from talent pooling candidates, recruitment of candidates, succession preparation phase, initial placement, the inaugural process, as well as guiding the newly elected leader to run the school. The new principal will need to acknowledge the school culture before he/she proposes the direction of improvement [14]. He/she needs to know the vision and mission of the school, areas to be improved, as well as the routine within the organization before leading the change.

Leadership succession in schools affects the organization performance naturally due to the change in communication and decision making process that happens between principal and teachers [3]. The existing differences in personality, working experience, and knowledge about the organization between the old and new principal will also impact the performance of the organization. Hence each new principal will give different personal style which will influence the overall school's performance.

\section{METHODS}

\section{A. Data Collection Method}

To answer what impacts a leadership succession have on school culture, a set of interviews were conducted. These interviews focus on the leadership behavior of the principals, situation of the school, and how both factors influenced the overall school culture.

To get a sense of the leadership behavior of the principals, this research focuses on both participants working experience (before acting as principal), his personal values, the school situation during his tenure, how he leads his school, and how he enact the school culture. This is followed by inquiry regarding school culture components [6] to explore whether there were changes during the first principal period and the current principal period.

\section{B. Context of the Research}

This research is conducted at a faith based school in Jakarta, Indonesia. The school is under the management a foundation board which is heavily linked to a christian church in Indonesia. The foundation has several school location, however the focus of this research is in one high school unit which has operated for only 6 years. 
During the 6 years span, it has two different principals. The first principal tenure was during the first 4 year of the high school and he resigned and was succeeded by the current principal.

\section{Research Participants}

The aim of the research is to describe how leadership succession impacts the school culture. To achieve this goal, this research used a qualitative study by interviewing a number of resources: both principals and teachers. The inclusion of teachers in the research is directed toward validating arguments of both principal to gain better understanding in differences of both leadership.

In order to decide which teachers should be included in the research, the researcher used a maximum variation technique. This technique would ensure that data collected should be rich enough [15], [16]. The variation taken into consideration were knowledge of teachers to both principals as well as working experience at the school. This should be rich enough to describe leadership behaviors of both principals and how it impacted the school culture. In the process, researcher asked both principals of potential teachers to be selected as participants, considering their familiarity with the principal figures, resulting in participants that highly favor the former principal, participants that highly favor the current principal, and participants somewhat in the middle between both principals. The teachers were varied in the relationship to the principal too. One participant was the vice principal of the first principal, while three others were teachers without any structural position.

\section{ANALYSIS}

\section{A. First Principal's Period}

\section{1) The school situation}

During the first four year since its formation, the school has few teachers to teach grade 10-12. This forces the school to rely on teachers of other units within the foundation who teach just on the scheduled day. The student body itself were not as many as current situation. This situation creates a lot of "empty classes" without any courses being taught. The first principal then had to be creative to fill in the empty classes. Therefore he made himself available and taught at the classes specifically motivating the students and explaining the philosophy of the school and other different activities.

As time went by, the number of teachers increased making the principal can focus more one the management of the school and not fill in the empty classes. Even with the increased number of teachers recruited, the total staff number in the school was relatively small. The principal often discuses on many topics with the staff making their relationship close.

\section{2) Principal profile}

The first principal's name is Andrew (not his real name). He had a bachelor degree in Economy and Master in Theology. His background in theology made him had a passion in christian based education philosophy which is a match to the foundation's value, vision, and mission. He enjoyed explaining the philosophy of education for the students and teachers during the empty class session in the first year of the school formation.

Andrew had been vice principal at a school unit within the foundation prior to his appointment as a principal, therefore he had experience with the bureaucracy of the school. In the second and third year, as the number of teachers increased, Andrew notice that there had been shift in the foundation's focus. The tend to focused more on the administrative tasks which could be burdening for the teachers. As a leader, Andrew decided that the teachers should concentrated more on the teaching and not be burdened by administrative tasks. Hence he did all the obliged tasks given by the foundation. This changes in focus, motivated Andrew to resign after the fourth year.

He only had three days before the appointment of the next principal, therefore he can only met the successor at the inaugural ceremony. However, he was open to help the current principal in leading the school. He backed his commitment by coming in the year after to discuss plenty of things he had not done in the transition period.

\section{3) Follower}

Given the circumstances, Andrew had a relatively small number of teachers to be coordinated. With the small number of teachers under his supervision, he often discuses and shares his opinion and passion about christian teaching to his staffs. He creates categorization of his teachers: partner (his vice principals who act as his assistant), disciple (the teachers who are not vice principals but often considered as future candidate of leaders) who were often shared his vision, and follower (the ordinary teachers). His categorization of teachers made him close to partners and disciples, however a little distant from the followers.

\section{B. Second Principal's Period}

\section{1) The school situation}

In the fourth year, the first principal decided to resign from his post. This was followed by the resignation of 5 teachers who were very close to the principal. Since then, the second principal was appointed by the foundation (he was senior teacher at different unit) with 26 teachers as his subordinate.

The teachers were divided into two groups: the first favoring the former principal and the second group favoring the newly appointed principal. The relation between principal and teachers no longer close as the number of student body increases (the school had three parallel classes for each grade) and the teachers' task also got more complicated. The principal also needed a lot of time to get to know each staff due to large number of teachers.

\section{2) Principal profile}

The second principal name was Benny (not the real name). He had a bachelor degree in computer engineering and master in theology. Unlike Andrew, who has been with the foundation prior to his appointment, Benny was recruited from other school. He had little knowledge about the foundation and school's circumstances at his disposal. The foundation also did not provide any brief or orientation, making him confused of his role and responsibility during his first year. 
To complicate matters, he also felt that the teachers were still in shock due to missing Andrew's figure. Some of them were quite resistant to Benny, although there were also teachers who were positive toward him. Benny tried to observe more of his subordinates before making any changes.

Unlike Andrew who often discuses topics with his teachers but were more directive, Benny used trust as the basis of his relation to his subordinates. Benny felt that, as adult, the teachers should have freedom in their action as long as they kept their responsibility fulfilled.

\section{3) Follower}

At the beginning of his tenure, Benny noticed the teachers were divided into two groups: those in favor of Andrew (mostly his partners and disciples) and those in favor of Benny. Faced by the grouping, Benny preferred to observe the teachers more. He would let the teachers do their own way as long as it meets the obligation. However, he would also not be hesitant to reprimand them if they do not meet their responsibility.

The teachers felt that he was not differentiating his actions to different groups of teachers. This is the positive aspect of Benny's leadership. However, the teachers felt that the freedom Benny gave to the teachers were too loose. The teachers felt there were lacking unity from the teachers.

\section{RESULTS}

\section{A. Comparison of the School Culture Components during the Principals Tenure}

\section{1) School's vision}

The school's vision were determined by the foundation. It was to educate students to know more and love Almighty God as to have character to be modeled by others. There were no changes in the vision during Andrew and Benny's tenure as principal. Andrew who was congenial to the foundation's vision statement then created a rite of spiritual activities (prayer, worship, as well as morning silent moment for reflective purposes). Benny still maintain the activities altogether. However, these activities had deterred as routine and were less meaningful to the students as well as the teachers.

\section{2) Values}

As happened with the school's vision statement, the values were derived from the foundation. However, in culminating the values in the organization, Andrew were concerned more with the process rather than result. To him, culminating good character starts from having discussion with the person of interest and it was much more beneficial rather than academic accomplishment. This was not the case in Benny's tenure. Benny gave freedom and flexibility to the teachers to do things differently as long as they meet the desired goals. This resulted in lack of sense of unity and uniformity among teachers.

\section{3) Basic assumptions and beliefs}

Andrew set three basic assumptions to the students and teachers: 1) the school exists because of God's work, 2) each students will spend three years enabling them to function for the next 30 years, 3) school will function as the second home. These assumptions were then translated to the policy of the school.

The first assumption were translated into customary action to ask for God's will before teachers as well as students decide on a matter. This was related to the vision of the foundation. Therefore he tried to balanced between discipline and love. He believes that no one should be punished directly after making a mistake and rather discuss it with the person to ensure they have a better understanding of the impact of his/her behavior.

"I had one student who always sloppy in his dress. It was hard to make him be neat. . I told him 'Do you like to have a principal who is sloppy dressed?' If you like it, then let us be sloppy in our dress' Then I explain them why was it important to be neat."

The second assumption were related on how serious all the process in school are for students. Every actions should be aimed toward the betterment of the students in the future. And lastly, Andrew wanted alumni, former teachers, and staff to feel school as their second home so that they might come back to school whenever possible. This was evident in the first and second generation of alumni who were still came to the school to meet the pupils and teachers and gave back to school.

All of the above assumptions were still held by Benny. However, the assumption of God's work in the school were perceived as misleading as teachers and staff often spend too much time for prayer when making decision, causing teachers and staff to feel that it takes a lot of time to make decision.

\section{4) Rites}

Since the school was a faith based institution whose vision was to educate pupils to know more and love God so that they might show a Godly character, Andrew set several religious practice to reach that vision. Morning reflection session as well as worship and prayer were conducted regularly for teachers and students.

Andrew also placed importance of teachers-students shared reflection session. He believed that the session would result in more caring among teachers and students.

Unlike in other school where ceremonies were held regularly to instill discipline and nationalism, Andrew only hold ceremonies for independence day. He felt that ceremonies like this could not be the appropriate way of teaching discipline to students.

In Benny's tenure, the foundation obliged the school to add reading the school philosophy book to its ritual. The principal also needed to be the first person to arrive at school and greetings every coming students. However this addition, together with the existing spiritual rituals, were a little meaningless. This happened because teachers were still had different ideas regarding the importance of the rites, which occur as consequences of the divided teachers. This also resulted from Benny's lack of knowledge of the foundation vision. This was also evident in the decreasing frequency of shared reflection session.

Benny also shared Andrew's belief of ceremonies. However, he also ensured on the $5^{\text {th }}$ week of a month there 
will be ceremonies. This was different from Andrew's tenure.

\section{5) Artifacts}

None of the architectural design changes during both principals tenure. And none of the architectural designs signifies any values held by the school community. Even the accomplishment of schools (such as trophies, or participation in science olympics, etc.) were not shown in the school environment. However, the foundation printed achievement of all units to be distributed to all pupils and parents. But this printed book not only represent the school's achievement but all achievement of units within the foundation. And no differences existed among both principals period of leadership.

\section{6) Stories and hero}

Andrew shared his story on how he was appointed as the principal and how he had to prepare and run the school with minimal help because limited teachers were available at that moment. This story was shared to each teachers as well as the pupils. He combined this with his passion of teaching christian education philosophy. And this happened when he had to fill in empty classes. It created sense of togetherness among school society members.

Unlike Andrew who had been with the foundation before he became principal, Benny and the new teachers he recruited had no idea regarding the history of the school, especially during Andrew's early years. Therefore Benny had no story to tell or inspire the students or teachers regarding the school.

\section{DISCUSSION}

Deal \& Peterson [6] stated that a school culture can be identified through its stated vision, values it strongly held, basic assumption and beliefs, as well as artifacts, rituals, and stories shared from generation to generation. The above case study indicated that the overall school culture were slightly shifting between Andrew (the first principal) and Benny (the second and current principal) tenure.

As the first principal, Andrew was heavily involved in laying out the foundation of the school culture. His passion in christian theology drove him to articulate the education process at school to achieve the stated vision statement of the foundation. Even when the circumstances were not ideal, he tried to direct his organization toward that goal. His personal conviction that the school was God's work and that its importance to school was very was then shared to teachers he saw as partners and disciple as well as the students of first generation. Worship, shared reflection session among teachers and students were evident of Andrew's personal belief. This was in accordance to Schein's levels of culture which stated that organizational culture stemmed of assumption which was strongly believed and highly valued and later be translated into action.

However, as Hoy and Miskel [3] stated, leadership succession brings only changes in practice. Benny, who was appointed with no prior experience in leading a school had difficulties to maintain Andrew's legacy. He maintained the overall practice and routine previously set by Andrew. However he lacked of understanding the rationale of the routine, resulting in activities with no or little meaning. Others than having no experience in school management, Benny also suffered from the lack of harmony in his subordinates, where parts of the teacher still favor Andrew over his leadership. This was worsen by the fact that in the process of succession, Benny only met once with Andrew and no discussions ever held among the two.

\section{CONCLUSION}

Based on the findings above, it can concluded that the change in the school culture happened because of the two leaders had differences in their character. The principals characters influenced how they articulate school vision and mission statement into daily practice.

Even when both principals had a master degree in Theology as educational background, both had different working experiences and personality. Andrew was more passionate in Christian education and willingly shares his philosophical conviction to his teachers, whereas Benny more humble person who lets his subordinates have a freedom as long as they fulfill their responsibilities.

Both Andrew and Benny leadership styles have strengths and weaknesses. Andrew, was seen as a visionary person and somewhat authoritarian in his implementation of christian value education. However he was also seen as someone who has personal preference in relating to teachers, whereas Benny was seen as equally just to all teachers but lack of futuristic direction.

\section{FUTURE WORK}

The implication of the finding only stresses the importance of transition process in educational leadership. This is especially evident since Benny, who actually had experience in teaching in different units still found difficulties leading the school. Transition and discussion among a leader and his/her successor is a pivotal to ensure the succession process is smooth. And since the school culture was heavily influenced by the principals' character, it is important to integrate the values, philosophical foundation of the principals when analysing the context of leadership in school. Future reseach should put more weigh in the characteristic of the leader.

\section{REFERENCES}

[1] D. Tjosvold and M. M. Tjosvold, Psychology for Leaders: Using Motivation, Conflict and Power to Manage Effectively, United States: John Wiley \& Sons, Inc., 1995, ch. 3, pp. 41-58.

[2] Teachers Assignment as Principal, Republic of Indonesia's Minister of National Education Regulation, 2010.

[3] W. K. Hoy and C. G. Miskel, Educational Administration: Theory, Research, and Practice, $6^{\text {th }}$ edition, New York: McGraw-Hill Companies, Inc., 2001, ch. 5, pp. 121-158.

[4] C. R. Wagner, "The school's leader tool for assessing and improving school culture," Principal Leadership, vol.7, pp. 41-44, 2006.

[5] R. Williamson and B. R. Blackburn, "A school culture audit," Principal Leadership, pp. 60-62, 2009.

[6] T. E. Deal and K. D. Peterson, The Shaping School Culture, San Fransisco: John Wiley \& Sons, Inc., 2002, ch. 2-6, pp. 7-85.

[7] A. D. Brown, Organisational Culture, $2^{\text {nd }}$ edition, London: Financia Times Management, ch. 2-4, pp. 41-159.

[8] G. E. Pawlas, "Vision and school culture," National Association of Secondary School Principals Bulletin, vol. 81, pp. 118-120, 1997. 
[9] J. R. Schermerhorn, J. G. Hunt, R. N. Osborn, and M. Uhl-Bien, Organizational Behavior, New Jersey: John Wiley \& Sons Inc., 2010, ch. 3, pp. 39-58

[10] R. L. Hughes, R. C. Ginnet, and G. J. Curphy, Leadership: Enhancing The Lessons of Experience, New York: McGraw-Hill Companies, 2009, ch. 1-2, pp. 3-45.

[11] Achdi, "Principal's leadership impact toward school productivity in Sumedang district: A case study at state and private owned high school in Sumedang," Thesis Magister, Education Management Department, Indonesia's Education University (UPI), Bandung, 2010.

[12] C. Brayman, K. Cooper, and R. E. White, Case Studies of Principal Rotation and Succession Policies: An International Perspective, Canada: Ontaria Principal's Counsil, pp. 51-60, 2006.

[13] D. Fink and C. Brayman, "School leadership succession and the challanges of change," Educational Administration Quarterly, vol. 1, no. 42, pp. 62-89, 2006.

[14] J. K. Clayton and B. Johnson, "If it ain't broke, don't fix it: A new principal is in town," Journal of Cases in Educational Leadership, vol. 4, no. 14, pp. 22-30, 2011.

[15] M. Q. Patton, Qualitative Research \& Evaluation Methods, $3^{\text {rd }}$ edition, California: Sage Publications Inc., 2002, ch. 8, pp. 431-539.

[16] E. K. Poerwandari, Qualitative Approach to Behavioral Research, Jakarta: Lembaga Pengembangan Sarana Pengukuran dan Pendidikan Psikologi Fakultas Psikologi Universitas Indonesia, 2009, ch. 7-8, pp 121-224.

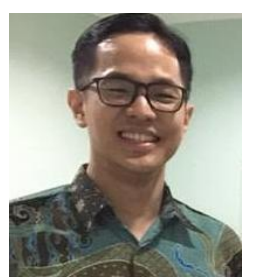

Ignatius Darma Juwono was born in Jakarta on July 24, 1982. He earned his bachelor degree in psychology from University of Indonesia in 2005 and graduated from Gadjah Mada University where he earned his master degree in professional psychology.

$\mathrm{He}$ is a faculty member at Atma Jaya Catholic University of Indonesia where he teaches introduction to pscyhology, educational psychology, introducation to psycho diagnostics, statistics, research methods, and few other course. He is now the Professional Psychology coordinator in Educational Psychology where his main responsibility is to manage students' internship before becoming a psychologist.

Mr. Juwono is a certified psychologist in education and a member of Indonesian Psychologist Association (Himpunan Psikologi Indonesia/HIMPSI).

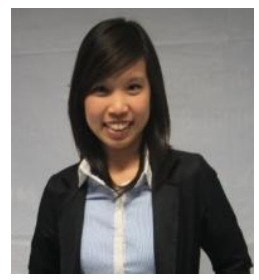

Tessar Harfin Harly was born in Jakarta, on August 28, 1991. She graduated from Atma Jaya Catholic University of Indonesia, majoring in psychology in 2013. 